\title{
ANALISIS SISTEM DAN PROSEDUR PENGADAAN KAS DAN PEMBAYARAN DANA PENSIUN PADA PT. POS INDONESIA CABANG MANADO
}

\author{
Gracia Miranda Putri ${ }^{1}$, Grace Nangoi ${ }^{2}$, Stanly Alexander ${ }^{3}$ \\ 1,2,3 Jurusan Akuntansi, Fakultas Ekonomi dan Bisnis, Universitas Sam Ratulangi, Jl. Kampus Bahu, Manado, \\ 95115, Indonesia \\ E-mail : gracia.m.putri@gmail.com
}

\begin{abstract}
Pension Funds play a very important role in the development of both economic and social welfare. The Pension Fund is a legal entity that manages and operates a program that promises retirement benefits. Implementation of cash procurement and pension fund payment at PT. Pos Indonesia Branch Manado can be done easily and does not take a long time because it uses a good system and procedures, and can illustrate how the implementation of internal controls on the procurement of cash and pension payments. The research method used in this thesis research is descriptive method whose purpose every data collected is analyzed and then drawn a conclusion and research type used is qualitative descriptive. The results obtained that the system and procedures of cash procurement and payment of pension funds at PT. Pos Indonesia Branch Manado runs well, in accordance with established standards, and is supported by the Fund Distribution system. Implementation of internal controls on the system and procedures of cash procurement and payment of pension funds at PT. Pos Indonesia Branch Manado has been run well because it is implemented in accordance with standard operating policy guidelines procedures and policies of directors. Keywords: System and Procedure, Cash Procurement, Pension Fund Payment.
\end{abstract}

\section{PENDAHULUAN}

Era modern ini segala kebutuhan hidup masyarakat semakin sulit dipenuhi. Gaya hidup yang tinggi membuat pengeluaran menjadi semakin besar. Biaya hidup yang besar serta tingkat kebutuhan yang tinggi menuntut seseorang tidak hanya bekerja untuk memenuhi kebutuhannya melainkan juga keinginannya. Oleh karena itu masyarakat lebih selektif untuk memilih lapangan pekerjaan yang menurutnya mampu memberikan penghasilan yang cukup untuk memenuhi kebutuhan dan keinginannya. Bekerja saja tidak cukup untuk memenuhi kebutuhan hidup apalagi ketika masyarakat telah berada dalam usia yang tidak lagi produktif dan tidak mampu lagi untuk bekerja. Hal ini membuat masyarakat berpikir untuk menginvestasikan penghasilan yang mereka dapatkan selama bekerja agar kebutuhan hidup di masa tua akan tercukupi.

Undang-Undang Republik Indonesia No. 11 tahun 1992 tentang Dana Pensiun menjelaskan Dana Pensiun adalah badan hukum yang mengelola dan menjalankan program yang menjanjikan manfaat pensiun, serta merupakan lembaga atau badan hukum yang mengelola program pensiun yang dimaksudkan untuk memberikan tunjangan kepada karyawan suatu perusahaan terutama yang telah memasuki masa lanjut usia. Wujud nyata dari jaminan hari tua adalah program pensiun, yang dikenal dengan Dana Pensiun Lembaga Keuangan (DPLK) dan Dana Pensiun Pemberi Kerja (DPPK). Pasal 1 Ayat 4 UndangUndang No. 11 Tahun 1992 menyatakan bahwa dana pensiun yang didirikan oleh Bank atau perusahaan asuransi jiwa untuk menyelenggarakan program pensiun iuran pasti bagi perorangan, baik bagi karyawan pemberi kerja maupun pekerja mandiri yang terpisah dari Dana Pensiun Pemberi Kerja bagi karyawan Bank atau Perusahaan Asuransi Jiwa yang bersangkutan merupakan definisi dana pensiun dari Dana Pensiun Lembaga Keuangan 
(DPLK) dan pasal 1 ayat 2 Undang-Undang Nomor 11 tahun 1992 menyatakan bahwa dana pensiun yang dibentuk oleh orang atau badan yang mempekerjakan karyawan, seperti pendiri, untuk mengadakan Program Pensiun Manfaat Pasti atau Program Pensiun Iuran Pasti, bagi kepentingan karyawannya sebagai peserta, dan yang menimbulkan kewajiban terhadap pemberi kerja merupakan definisi dana pensiun dari Dana Pensiun Pemberi Kerja (DPPK).

PT. Pos Indonesia (Persero) mengadakan kerjasama dengan PT. Taspen (Persero) dalam pembayaran pensiun. Penerimaan pensiun merupakan individu atau ahli warisnya yang menerima atau memperoleh imbalan atas pekerjaan yang dilakukan di masa lalu, termasuk individu atau ahli warisnya yang menerima tunjangan hari tua. Untuk mempermudah para pensiunan dalam mengambil uang pensiunannya, maka PT. Taspen (Persero) memberikan kepercayaan kepada PT. Pos Indonesia (Persero) sebagai badan pembantu dalam pembayaran pensiun. PT. Taspen mendapat dana pensiun dari Anggaran Pendapatan dan Belanja Negara (APBN) karena setiap program pensiun dibiayai, terutama dari Anggaran Pendapatan dan Belanja Negara (APBN).

Pada PT. Pos Indonesia, sistem dan prosedur pembayaran dana pensiun harus dimulai dengan pengadaan kas terlebih dahulu pada bagian jurubayar. Setelah pengadaan kas selesai, bagian jurubayar diperbolehkan untuk membayarkan manfaat pensiun kepada peserta, maka dari itu, perlu dilakukan penelitian untuk mengetahui bagaimana prosedur pengadaan kas dan pembayaran dana pensiun yang sudah berjalan dengan baik dan sesuai dengan prosedur, dan bagaimanakah pelaksanaan pengendalian internal dalam pengadaan kas dan pembayaran dana pensiun.

\section{TINJAUAN PUSTAKA}

\subsection{Sistem Akuntansi}

Hery (2012:7) menyatakan bahwa akuntansi merupakan sebuah sistem informasi yang memberikan laporan kepada para pengguna informasi akuntansi atau kepada pihak-pihak yang memiliki kepentingan terhadap hasil kinerja dan kondisi keuangan masyarakat. Menurut Warren, Reeve, Fees (2013:206) pengertian sistem akuntansi adalah metode dan prosedur untuk mengumpulkan, mengklarifikasikan, mengikhisarkan dan melaporkan informasi operasi dan keuangan sebuah perusahaan. Maka dapat dikatakan bahwa sistem akuntansi adalah organisasi formulir-formulir catatan-catatan, prosedur-prosedur, alat-alat, dan sumber daya manusia untuk menghasilkan umpan balik dalam bentuk laporan-laporan yang diperlukan oleh pihak manajemen dan pihak-pihak yang berkepentingan lainnya.

\subsection{Standar Operasional Prosedur}

SOP adalah urutan langkah-langkah (atau pelaksanaan-pelaksanaan pekerjaan), dimana pekerjaan tersebut dilakukan, berhubungan dengan apa yang dilakukan, bagaimana melakukannya, bilamana melakukannya, di mana melakukannya, dan siapa yang melakukannya (Moekijat, 2008). Maka dapat disimpulkan bahwa SOP merupakan pedoman kerja bagi setiap organisasi atau perusahaan dalam menjalankan kegiatan operasionalnya.

\subsubsection{Tujuan Standar Operasional Prosedur}

Hartatik (2014:30) menyatakan bahwa terdapat beberapa tujuan SOP, antara lain:

1.Untuk menjaga konsistensi tingkat penampilan kinerja atau kondisi tertentu dan kemana petugas dan lingkungan dalam melaksanakan sesuatu tugas atau pekerjaan tertentu;

2.Sebagai acuan dalam pelaksanaan kegiatan tertentu bagi sesama pekerja dan supervisor;

3.Agar terhindar dari kegagalan atau kesalahan (dengan demikian bisa menghindari dan mengurangi suatu konflik), keraguan, serta pemborosan dalam proses pelaksanaan kegiatan;

4.Merupakan parameter untuk menilai mutu pelayanan;

5.Untuk lebih menjamin keefisienan dan keefektifan penggunaan tenaga dan sumber daya; 
6.Untuk mengetahui dengan jelas alur tugas, wewenang dan tanggung jawab dari petugas yang terkait;

7.Sebagai dokumen yang dapat menjelaskan dan menilai pelaksanaan proses kerja bila terjadi suatu kesalahan, misalnya kesalahan administratif sehingga sifatnya melindungi;

8.Sebagai dokumen yang digunakan untuk pelatihan; dan

9.Sebagai dokumen sejarah bila telah dibuat revisi SOP yang baru.

\subsubsection{Fungsi Standar Operasional Prosedur}

Hartatik (2014:35) menyatakan bahwa terdapat beberapa fungsi Standar Operasional Prosedur (SOP), antara lain:

1.Memperlancar tugas petugas atau pegawai maupun tim atau unit kerja;

2.Sebagai dasar hukum bila terjadi penyimpangan;

3.Mengetahui dengan jelas hambatan-hambatannya dan mudah dilacak;

4.Mengarahkan petugas atau pegawai untuk sama-sama disiplin dalam bekerja; dan

5.Sebagai pedoman dalam melaksanakan pekerjaan rutin.

\subsection{Pengertian Kas}

Pengertian kas menurut Martani (2012:180) adalah aset keuangan yang digunakan untuk kegiatan operasional perusahaan. Kas merupakan aset yang paling likuid karena dapat digunakan untuk membayar kewajiban perusahaan. Sedangkan, menurut Effendi (2013:191) dari segi akuntansi yang dimaksud dengan kas adalah segala sesuatu (baik yang berbentuk uang atau bukan) yang dapat digunakan sebagai alat pembayaran atau alat pelunasan kewajiban.

\subsection{Pengendalian Internal}

Dalam upaya mencapai tujuan utama, tiap perusahaan sudah sepatutnya memiliki suatu alat yang dapat dijadikan kontrol atas kinerja dan sistem yang berjalan didalamnya. Alat tersebut adalah pengendalian internal atau Internal Control. Pengendalian internal merupakan cara yang dilakukan manajemen perusahaan untuk mengurangi potensi timbulnya kecurangan yang mungkin terjadi dalam sistem yang ada di perusahaan.

\subsubsection{Tujuan Pengendalian Internal} berikut:

Tujuan pokok pengendalian internal menurut Mulyadi (2016:129) adalah sebagai

1.Menjaga kekayaan organisasi,

2.Mengecek ketelitian dan keandalan data akuntansi,

3.Mendorong efisiensi, dan

4.Mendorong dipatuhinya kebijakan manajemen.

\subsubsection{Unsur-Unsur Pengendalian Internal}

Komponen pengendalian internal menurut Commite of Sponsoring of Organization (COSO) dalam Internal Control - Integrated Framework (2013: 6-7), bahwa pengendalian internal memiliki lima komponen yang saling berhubungan, yaitu:

1. Lingkungan Pengendalian (Control Environment)

Perusahaan yang mencakup sikap para manajemen dan karyawan terhadap pentingnya pengendalian yang ada di organisasi tersebut.

2. Penilaian Risiko (Risk Assestment)

Semua organisasi memiliki risiko, yaitu dalam kondisi apapun yang namanya risiko pasti ada dalam suatu aktivitas, baik aktivitas yang berkaitan dengan bisnis maupun non bisnis.

3. Aktivitas Pengendalian (Control Activities)

Untuk menstandarisasi proses kerja sehingga menjamin tercapainya tujuan perusahaan dan mencegah atau mendeteksi terjadinya ketidakberesan dan kesalahan.

4. Informasi dan Komunikasi (Information and Communication) 
Informasi dan komunikasi merupakan unsur-unsur yang penting dari pengendalian internal perusahaan. Informasi tentang lingkungan pengendalian, penilaian risiko, prosedur pengendalian, dan pemantauan diperlukan oleh manajemen untuk pedoman operasional dan menjamin ketaatan dengan pelaporan hukum serta peraturan-peraturan yang berlaku pada perusahaan.

\section{Aktivitas Pemantauan (Monitoring Activities)}

Aktivitas pemantauan terhadap sistem pengendalian internal akan menemukan kekurangan serta meningkatkan efektivitas pengendalian. Pengendalian internal dapat di monitor secara efektif melalui penilaian khusus atau sejalan dengan usaha manajemen.

\subsection{Dana Pensiun}

Dana Pensiun berperan sangat penting dalam pembangunan baik dari ekonomi maupun kesejahteraan sosial. Beberapa sumber memberikan pengertian dana pensiun atau pensiun fund sebagai berikut. Definisi Dana Pensiun menurut Undang-Undang Republik Indonesia No. 11 Tahun 1992 Pasal 1 ayat 1 adalah badan hukum yang mengelola dan menjalankan program yang menjanjikan manfaat pensiun.

\subsubsection{Tujuan Dana Pensiun}

Penyelenggaraan dana pensiun tidak bisa dilihat secara sederhana, di sana memiliki berbagai dimensi tujuan (Fahmi, 2014:177). Bagi pemberi kerja tujuan untuk menyelenggarakan dana pensiun bagi karyawannya adalah sebagai berikut:

1. Memberikan suatu penghormatan kepada karyawan yang telah bekerja dengan baik di perusahaan tersebut.

2. Karyawan tersebut tetap dapat menikmati hasil yang diperoleh pada saat memasuki usia pensiun setelah bekerja di perusahaannya.

3. Memberikan keamanan dari segi batin sehingga dapat menurunkan turn over karyawan.

4. Meningkatkan semangat kerja karyawan dalam melaksanakan tugas sehari-hari.

\subsubsection{Manfaat Pensiun}

Taswan (2015:5) menyatakan bahwa manfaat pensiun terdiri atas:

1. Manfaat Pensiun Normal;

2. Manfaat Pensiun Dipercepat;

3. Manfaat Pensiun Cacat;

4. Manfaat Pensiun Ditunda;

5. Manfaat Pensiun Janda/Duda atau Anak.

\subsection{Penelitian terdahulu}

Beberapa penelitian terdahulu yang penulis jadikan sebagai bahan pertimbangan dalam melakukan penelitian di PT. Pos Indonesia Cabang Manado. Penelitian yang dilakukan oleh Weny Malinda tahun 2012 tentang Sistem Pembayaran Pensiunan pada nasabah yang dilaksanakan pada PT. Bank Tabungan Pensiunan Nasional cabang Salatiga, menyatakan bahwa prosedur pembayarannya dapat dijelaskan dalam tiga hal, yaitu prosedur penerimaan calon nasabah pensiunan, prosedur penerimaan daftar gaji nasabah pensiunan, dan prosedur pembayaran dana pensiun ke Nasabah. Sebelum tahun 2009, PT. BTPN belum melakukan transaksi secara online, dan PT. BTPN melakukan transaksi secara online sejak bulan Desember 2009.

\section{METODE PENELITIAN}

\subsection{Jenis Penelitian}

Metode penelitian pada dasarnya merupakan cara ilmiah untuk mendapatkan data dengan tujuan dan kegunaan tertentu (Sugiyono, 2014:3). Penelitian yang dilakukan dalam penelitian ini merupakan Penelitian Deskriptif. Penelitian Deskriptif merupakan penelitian yang menjelaskan setiap data yang diperoleh, fenomena yang terjadi dan hasil penelitian di lapangan yang ditemukan, dalam bentuk kata-kata yang menceritakan, mengemukakan dan 
menggambarkan situasi tersebut yang memiliki makna sesuai dengan hasil penelitian yang dilakukan. Menurut Sugiyono (2014:22) metode deskriptif adalah metode yang digunakan menggambar atau menganalisis suatu hasil penelitian tetap tidak digunakan untuk membuat kesimpulan yang lebih luas.

\subsection{Waktu dan Tempat Penelitian}

Penelitian dilakukan di PT. Pos Indonesia Cabang Manado yang bertempat di Jl. Sam Ratulangi, Wenang Utara, Kota Manado, Sulawesi Utara. Waktu Penelitian dimulai dari bulan Maret sampai dengan bulan April 2018.

\subsection{Prosedur Penelitian}

Mengidentifikasikan masalah, menentukan objek penelitian, penyusunan proposal penelitian, pengumpulan data, menganalisis dan mengolah data, kemudian memperoleh hasil penelitian, lalu ditarik kesimpulan dan memberikan saran.

\subsection{Metode Analisis}

Sugiyono (2014:3) menyatakan metode penelitian pada dasarnya merupakan cara ilmiah untuk mendapatkan data dengan tujuan dan kegunaan tertentu yang digunakan untuk menggambar atau menganalisis suatu hasil penelitian tetapi tidak digunakan untuk membuat kesimpulan yang lebih luas. Metode penelitian yang digunakan dalam penelitian ini adalah metode deskriptif.

\section{HASIL ANALISIS DAN PEMBAHASAN \\ 4.1 Hasil analisis}

\subsubsection{Prosedur Pengadaan Kas untuk Pembayaran Dana Pensiun}

Sebelum melakukan proses pembayaran dana pensiun, terlebih dahulu dilakukan proses pengadaan kas. Kas ini berfungsi untuk membayarkan sejumlah dana pensiun yang akan diperoleh peserta. Prosedur pengadaan kas yang dilaksanakan pada PT. Pos Indonesia Cabang Manado, yaitu sebagai berikut:

a.Prosedur Pengadaan Kas

1. Setiap hari bagian jurubayar harus mengambil panjar dana pensiun dari bagian keuangan dengan jumlah yang berbeda.

2. Bagian jurubayar pergi ke bagian keuangan dan menulis di buku panjar berapa jumlah uang yang diterima jurubayar untuk pembayaran dana pensiun, lalu ditandatangani oleh jurubayar.

3. Lalu, bagian keuangan memberikan jumlah dana pensiun kepada jurubayar sesuai dengan yang tertulis di buku panjar.

b.Prosedur Pengembalian Kas

1. Setelah selesai melakukan aktivitas pembayaran, jurubayar mengembalikan sisa uang yang ada ke bagian keuangan sesuai dengan backsheet dan transaksi yang terjadi.

2. Lalu, bagian keuangan mencocokkan setoran uangnya dengan backsheet dan mengclosingnya, sebagai bukti bahwa pembayaran dana pensiun pada hari itu telah selesai.

3. Setelah itu, bagian keuangan mengkompilasinya di neraca kasir. Neraca kasir berisi berapa uang yang dipanjar dan berapa setoran yang kembali.

4. Selain itu, selesai melakukan aktivitas pembayaran, bagian jurubayar juga memberikan backsheet ke bagian pelayanan untuk diperiksa dan ditandatangani.

\subsubsection{Prosedur Pembayaran Manfaat Pensiun Peserta}

Prosedur pembayaran manfaat pensiun yang dilaksanakan pada PT. Pos Indonesia

Cabang Manado, yaitu sebagai berikut:

1. Pembayaran manfaat pensiun dilakukan pada tanggal 1 sampai dengan tanggal 28 setiap bulannya.

2. Peserta yang ingin mengambil manfaat pensiunnya, harus mengisi slip penarikan terlebih dahulu. 
3. Peserta pensiun juga harus membawa Kartu Identitas Pensiun (Karip).

4. Untuk sistem rekeningsasi, dilakukan auntetikasi, yaitu dilakukan pemeriksaan apakah yang mengambil manfaat pensiun tersebut adalah orang yang bersangkutan atau mewakili peserta yang sebenarnya.

5. Untuk pembayaran manfaat pensiun, menggunakan sistem online untuk pembayaran manfaat pensiun yang bernama Fund Distribution.

6. Setelah masuk ke Fund Distribution, hanya diperlukan nomor rekening peserta. Setelah log in menggunakan nomor rekening, akan muncul identitas peserta manfaat pensiun tersebut, seperti nama, alamat, tempat tanggal lahir, jenis pensiun, nomor pensiun, beserta pas foto.

7. Setelah itu, pilih nomor pensiun. Lalu, nomor pensiunnya dimasukkan ke dalam sistem untuk di validasi.

8. Setelah memasukkan nomor pensiun peserta, akan muncul data peserta, seperti nama, alamat, besarnya jumlah manfaat pensiun yang akan diterima peserta, dan pensiun bulan apa.

9. Jika peserta ada pinjaman di bank/koperasi akan ada kwitansi yang diterbitkan. Tiap akhir bulan bank/koperasi memberikan rekapan nama dan lampiran kwitansinya, jadi peserta akan menerima manfaat pensiun yang telah dikurangi oleh pinjaman di bank/koperasi.

10. Lalu datanya dicetak, biasanya disebut cetak resi.

11. Setelah resinya dicetak, manfaat pensiun tersebut dibayarkan kepada peserta sesuai dengan jumlah yang tertera pada resi. Lalu, peserta menandatangani resi tersebut sebagai bukti bahwa peserta telah menerima manfaat pensiun.

12. Jurubayar membuat backsheet setiap transaksi yang terjadi, yang tertulis berapa jumlah uang yang dibayarkan untuk dana pensiun, atas berapa orang, dan berapa sisa uangnya.

\subsubsection{Fungsi/bagian yang terkait dalam Pengadaan Kas dan Pembayaran Dana Pensiun}

Dalam pelaksanaan sistem dan prosedur pengadaan kas dan pembayaran dana pensiun pada PT. Pos Indonesia Cabang Manado terdapat fungsi/bagian yang terkait didalamnya:

1. Bagian Keuangan;

2. Bagian Jurubayar;

3. Bagian Pelayanan.

\subsubsection{Dokumen yang terkait dalam Pengadaan Kas dan Pembayaran Dana Pensiun}

Dokumen yang digunakan dalam sistem dan prosedur pengadaan kas dan pembayaran dana pensiun pada PT. Pos Indonesia Cabang Manado adalah:

1.Dokumen Pendukung

a.Slip Penarikan;

b.KARIP (Kartu Identitas Pensiun);

c.Surat Kuasa;

d.Kwitansi.

2.Dokumen Proses

a.LRPP (Laporan Realisasi Pembayaran Pensiun);

b.LSUP (Laporan Saldo Uang Pensiun);

c.SUP3;

d.Backsheet.

\subsubsection{Catatan yang digunakan dalam Pengadaan Kas dan Pembayaran Dana Pensiun}

Catatan akuntansi yang digunakan dalam proses pengadaan kas dan pembayaran dana pensiun adalah sebagai berikut:

1.Sistem Fund Distribution;

2.Buku Panjar; 
3.Neraca Kasir.

\subsection{Pembahasan}

\subsubsection{Analisis Sistem dan Prosedur Pengadaan Kas dan Pembayaran Dana Pensiun}

Dalam pelaksanaan sistem dan prosedur pengadaan kas dan pembayaran dana pensiun pada PT. Pos Indonesia Cabang Manado sudah dijalankan dengan baik sesuai dengan Standar Operasional Prosedur (SOP) yang ditetapkan oleh PT. Pos Indonesia. Prosedur awal yang harus dilakukan sebelum melakukan proses pembayaran dana pensiun, yaitu melakukan pengadaan kas. Bagian jurubayar setiap hari mengambil panjar terlebih dahulu di bagian keuangan sebelum melakukan aktivitas pembayaran. Setelah selesai, bagian jurubayar menyetor kembali dana yang tersisa ke bagian keuangan. Lalu, bagian keuangan mencocokkan dengan backsheet transaksi yang terjadi, untuk menyesuaikan jumlah yang disetor kembali sama seperti yang ada di backsheet. Setelah itu, jurubayar memberikan backsheet ke bagian pelayanan untuk diperiksa dan ditandatangani.

Sistem pembayaran dana pensiun, PT. Pos Indonesia Cabang Manado menggunakan sistem Fund Distribution. Dalam sistem ini, terdapat identitas semua peserta pensiun. Jadi, setiap nomor peserta pensiun dimasukkan ke dalam sistem ini untuk di validasi. Setelah memasukkan nomor pensiun peserta, akan muncul data peserta, seperti nama, alamat, besarnya jumlah manfaat pensiun yang akan diterima peserta, dan pensiun bulan ke berapa. Dalam melaksanakan proses pembayaran dana pensiun, sistem ini sangat efektif dan efisien. Efektif, dalam melaksanakannya tidak perlu menunggu waktu yang lama untuk proses pembayaran pensiun karena hanya diperlukan nomor peserta pensiun untuk di log in ke sistem tersebut. Setelah itu, akan muncul data lengkap peserta pensiun. Jumlah yang akan diterima peserta juga tertera di sistem tersebut tanpa harus menghitung secara manual. Karena setiap manfaat pensiun yang diterima peserta jumlahnya berbeda, tergantung besarnya gaji, jabatan, dan golongan. Efisien, dalam pelaksanaannya tidak memerlukan banyak kertas untuk melaksanakan proses pembayaran dana pensiun ini. Bagian jurubayar hanya perlu mencetak tanda terima penarikan rekening (resi) yang kemudian di tandatangani oleh peserta sebagai bukti bahwa peserta telah menerima manfaat pensiun. Namun, terdapat beberapa masalah yang membuat sistem ini tidak berjalan dengan baik, yaitu gangguan jaringan internet dalam kantor sehingga sistem ini sangat sulit diakses. Jika terjadi gangguan, aktivitas pembayaran akan terhenti, dan bagian jurubayar tidak bisa berbuat apa-apa, selain menunggu jaringan internet stabil kembali. Biasanya, peserta hanya bisa menunggu atau kembali lagi pada besok hari untuk mengambil manfaat pensiunnya.

Fungsi/bagian yang terkait dalam pengadaan kas dan pembayaran dana pensiun juga sudah berjalan dengan baik, karena dalam pelaksanaan pembayaran dana pensiun harus melewati beberapa bagian yang terpisah, yaitu bagian keuangan, jurubayar, dan pelayanan. Bagian jurubayar diwajibkan untuk mengembalikan sisa dana pensiunnya setiap hari disertakan dengan laporan kerjanya (backsheet) sehingga tidak ada potensi untuk melakukan kecurangan terkait dengan dana pensiun. Bagian keuangan selalu memeriksa sisa dana yang kembali, apakah telah sesuai dengan transaksi yang terjadi atau tidak. Bagian jurubayar juga selalu memberikan backsheet ke bagian pelayanan untuk diperiksa dan ditandatangani karena pembayaran dana pensiun ini, berada dalam pengawasan bagian pelayanan.

Dokumen yang digunakan terkait dengan pengadaan kas dan pembayaran dana pensiun menggunakan nomor urut cetak sehingga memudahkan saat melakukan pencarian dan penyimpanan dokumen yang terkait dengan pembayaran dana pensiun.

Catatan yang digunakan terkait dengan sistem dan prosedur pengadaan kas dan pembayaran dana pensiun telah menggunakan sistem pencatatan komputerisasi. Dengan adanya sistem pencatatan yang terkomputerisasi, maka pencatatan menjadi cepat dan akurat sehingga kesalahan dalam mencatat menjadi kemungkinan yang sangat kecil. 
Dengan adanya sistem yang memadai, Standar Operasional Prosedur (SOP), tujuan, dan otoritas yang jelas, maka dari itu, dapat dikatakan bahwa sistem dan prosedur pengadaan kas dan pembayaran dana pensiun kepada peserta sudah berjalan dengan baik. Selain itu, persyaratan untuk pengambilan manfaat pensiun sudah sangat jelas dan memudahkan seluruh peserta sehingga tidak perlu memakan waktu yang lama untuk mengambil manfaat pensiunnya.

\subsubsection{Analisis Pengendalian Internal dalam Pengadaan Kas dan Pembayaran Dana Pensiun}

Berdasarkan hasil penelitian, dapat dilihat bagaimana jalannya pengendalian internal yang dilaksanakan PT. Pos Indonesia Cabang Manado dalam pengadaan kas dan pembayaran dana pensiun dilihat dari unsur-unsur pengendalian internal menurut Committee of Sponsoring Organizations (COSO) adalah sebagai berikut:

1. Lingkungan Pengendalian (Control Environment)

Dalam pelaksanaan pengadaan kas dan pembayaran dana pensiun, manajemen dan pegawai telah menunjukkan integritas dan nilai-nilai etika yang baik. Begitu juga dengan komitmen dalam bekerja yang sesuai dengan Standard Operating Procedur (SOP). Dewan direksi dan komite audit semakin ketat dan teliti terhadap semua proses pekerjaan yang telah berjalan pada PT. Pos Indonesia Cabang Manado, baik dalam proses pengadaan kas maupun proses pembayaran dana pensiun. Dewan komisaris dan komite audit juga melakukan sosialisasi mengenai aturan dalam bekerja sesuai dengan SOP dan agar tidak terjadi kecurangan saat bekerja. PT. Pos Indonesia Cabang Manado telah menetapkan struktur, jalur-jalur pelaporan, wewenang-wewenang dan tanggung jawab, yang dilakukan secara bertingkat mulai dari wewenang terendah sampai kepada pemutus akhir dan setiap unit sudah memiliki job desk masing-masing berdasarkan SOP dan surat edaran direksi. PT. Pos Indonesia Cabang Manado selalu melakukan pergantian bagian pekerjaan. Setiap pegawai tidak terlalu lama berada di bagian yang mereka kerjakan, karena jika terlalu lama, akan ada kejenuhan dan terbuka cela untuk melakukan kecurangan. PT. Pos Indonesia Cabang Manado menggunakan audit komite sebagai pengawas terhadap kebijakan-kebijakan usaha, unit kendali internal yang melakukan monitor bulanan terhadap kinerja di setiap unit kerja.

2. Penilaian Risiko (Risk Assestment)

PT. Pos Indonesia Cabang Manado telah menetapkan tujuan dengan jelas, namun belum semua yang tercapai dan pasti akan tercapai, dan dapat dilihat bahwa kinerja setiap unit kerja yang selalu maksimal mampu mengatasi risiko yang ada. Untuk mengidentifikasi resiko pengadaan kas dan pembayaran pensiun, PT. Pos Indonesia Cabang Manado mengontrol proses pengadaan kas dan pembayaran manfaat pensiun sehingga memenuhi SOP. Oleh karena itu, pekerjaan yang dikerjakan berlangsung dengan baik dan memenuhi kepuasan peserta. Dalam mempertimbangkan potensi kecurangan, PT. Pos Indonesia Cabang Manado melakukan uji petik yang merupakan rahasia komite audit untuk menguji kinerja pelayanan. Disitu peserta akan menjawab pertanyaan yang diajukan. Uji petik dilakukan secara rahasia tanpa diketahui oleh pegawai. Setiap perubahan yang terjadi pada PT. Pos Indonesia Cabang Manado dikontrol dengan cara memonitoring percepatan dampak perubahan aturan terhadap hasil kerja perusahaan. Contohnya, perubahan sistem pembayaran dari manual ke sistem online, pernah terjadi sedikit kendala pada perubahan tersebut. Tetapi, pihak PT. Pos Indonesia dapat melewatinya dengan baik karena adanya pengawasan yang baik sehingga masalah yang ada tidak menjadi hambatan untuk pelayanan dan pelayanan dapat berjalan dengan baik.

3. Aktivitas Pengendalian (Control Activities)

Aktivitas pengendalian internal terhadap sistem dan prosedur pengadaan kas dan pembayaran dana pensiun pada PT. Pos Indonesia Cabang Manado dilaksanakan dengan 
baik, didukung dengan adanya otorisasi yang jelas. Pengawasan selalu dilakukan agar tidak ada kesempatan untuk melakukan kecurangan pada saat pelaksanaan pengadaan kas dan pada saat membayarkan manfaat pensiun kepada peserta kaum lansia (lanjut usia). Aktivitas pengendalian atas teknologi yang dilaksanakan pada PT. Pos Indonesia Cabang Manado dikontrol dengan melakukan kerjasama dengan vendor jaringan dan aplikasi aman dan dapat dijamin kerahasiaan data penggunaannya. PT. Pos Indonesia Cabang Manado dalam hal ini selalu menegaskan aturan terkait rahasia perusahaan kepada karyawan sehingga pegawai paham akan hak dan kewajibannya serta aturan yang berlaku dimana pegawai itu bekerja.

4. Informasi dan Komunikasi (Information and Communication)

Dalam memperoleh informasi yang berkualitas dalam sistem dan prosedur pengadaan kas dan pembayaran dana pensiun, PT. Pos Indonesia Cabang Manado selalu berkoordinasi dengan PT. Taspen. Jika ada peserta yang baru, PT. Pos Indonesia dan PT. Taspen selalu mengkomunikasikannya dengan baik untuk mempererat hubungan kerja sama. Manajemen PT. Pos Indonesia Cabang Manado melakukan sosialisasi untuk aturan baru agar kepatuhan dan tanggungjawab terhadap aturan yang berlaku tetap berjalan dengan baik. Dalam pelaksanaan pembayaran manfaat pensiun, PT. Pos Indonesia Cabang Manado memberitahu peserta tentang persyaratan yang harus dipenuhi pada saat menjadi peserta pensiun dan pada saat mengambil manfaat pensiun.

5. Aktivitas Pemantauan (Monitoring Activities)

Pelaksanaan pegawasan pengendalian internal atau pemantauan terhadap proses pengadaan kas dan pembayaran dana pensiun pada PT. Pos Indonesia Cabang Manado selalu dilaksanakan dan wajib dilaporkan atas kinerja setiap unit dibuktikan dengan laporan kinerja bulanan dan wajib melaporkan hasil pengawasan untuk meminimalkan risiko yang tidak dinginkan. PT. Pos Indonesia Cabang Manado adalah salah satu mitra bayar dari PT. Taspen, maka dari itu PT. Taspen juga selalu melakukan pengawasan secara tiba-tiba untuk melihat bagaimana sistem pembayaran di PT. Pos Indonesia Cabang Manado.

\section{KESIMPULAN DAN SARAN \\ 5.1 Kesimpulan}

Berdasarkan hasil penelitian dan pembahasan yang telah dikemukakan sebelumnya, maka dapat diambil kesimpulan bahwa PT. Pos Indonesia Cabang Manado telah melaksanakan sistem dan prosedur pengadaan kas dan pembayaran dana pensiun dengan baik, dan sesuai dengan Standar Operasional Prosedur (SOP) yang ditetapkan perusahaan. Proses pembayaran dana pensiun juga didukung dengan sistem Fund Distribution yang dapat memberikan kemudahan dalam proses pembayaran dana pensiun. Untuk pelaksanaan proses pembayaran dana pensiun, fungsinya dilakukan secara terpisah, didukung dengan dokumen dan catatan yang sesuai sehingga pembayaran dana pensiun yang dilakukan sudah maksimal. Pelaksanaan unsur-unsur pengendalian internal pada sistem dan prosedur pengadaan kas dan pembayaran dana pensiun pada PT. Pos Indonesia Cabang Manado telah memenuhi 5 unsur pengendalian internal menurut Committee of Sponsoring Organizations (COSO), yaitu lingkungan pengendalian, penilaian resiko, aktivitas pengendalian, informasi dan komunikasi, dan aktivitas pemantauan.

\subsection{Saran}

Berdasarkan hasil penelitian dan analisis yang dilakukan sebelumnya, agar dapat meningkatkan kinerja sistem dan prosedur pengadaan kas dan pembayaran dana pensiun Cabang Manado, penulis memberikan saran antara lain: 
1. Untuk proses pengadaan kas dan pembayaran dana pensiun pada PT. Pos Indonesia Cabang Manado secara keseluruhan telah berjalan dengan baik, hal ini harus dipertahankan. Akan tetapi, jika ada mekanisme yang lebih baik lagi kedepannya mengenai proses pembayaran dana pensiun, PT. Pos Indonesia harus bisa menerapkan dan menyesuaikannya agar proses pengadaan kas dan pembayaran dana pensiun dapat ditingkatkan dan dapat berjalan dengan baik.

2. Untuk pengendalian internal dalam pembayaran dana pensiun, sudah dijalankan dengan baik. Akan tetapi, jika ada perubahan struktur organisasi, tugas, wewenang, dan tanggungjawab, pegawai harus bisa dengan segera menyesuaikan, menguasai, dan mempertanggungjawabkan tugas yang diberikan dengan baik agar tidak terjadi penyalahgunaan tugas dan wewenang.

\section{DAFTAR PUSTAKA}

Commite of Sponsorsing Organizations (COSO). 2013. Internal Control - Integrated Framework: Executive Summary. Durham. North Carolina.

Fahmi, Irham. 2014. Pengantar Manajemen Keuangan. Alfabeta. Bandung.

Hartatik, P. Indah. 2014. Buku Praktis Mengembangkan SDM. Laksana. Yogyakarta.

Hery. 2012. Analisis Laporan Keuangan. Bumi Aksara. Jakarta.

Martani, Dwi. 2012. Akuntansi Keuangan Menengah Berbasis PSAK. Salemba Empat. Jakarta.

Moekijat. 2008. Manajemen Kepegawaian dan Hubungan dalam Perusahaan. Edisi Ketiga. Alumni Bandung.

Mulyadi. 2016. Sistem Akuntansi. Salemba Empat. Jakarta.

Sugiyono. 2014. Metode Penelitian Kuantitatif, Kualitatif dan R\&D. Alfabeta. Bandung.

Taswan. 2015. Akuntansi Perbankan Transaksi dalam Valuta Rupiah. Edisi Ketiga. UPP STIM YKPN. Yogyakarta.

Undang-undang Republik Indonesia Nomor 11 Tahun 1992. Dana Pensiun. 20 April 1992. Lembaran Negara Republik Indonesia Tahun 1992. Jakarta.

Warren, C. S., Reeve, J. M., dan Fees, P. E. 2013. Pengantar Akuntansi. Buku Satu. Edisi 21. Salemba Empat. Jakarta. 